\title{
Validation of an instrument to measure the quality of life in children with oropharyngeal mucositis undergoing cancer treatment
}

\author{
Rosaura Gutiérrez-Vargas ${ }^{1}$, Eduardo Velasco-Rojano², Miguel Á. Villasís-Keever ${ }^{3}$, \\ Javier Portilla-Robertson ${ }^{4}$, Araceli Gutiérrez-Rodelo ${ }^{5}$, Sonny Flores-Navarro ${ }^{6}$, Luis E. Juárez-Villegas ${ }^{7}$ and \\ Marta Zapata-Tarrés ${ }^{8 *}$ \\ ${ }^{1}$ Programa de Maestría y Doctorado en Ciencias Médicas, Odontológicas y de la Salud, Universidad Nacional Autónoma de México, Mexico City; \\ ${ }^{2}$ Universidad Nacional Autónoma de México, Mexico City; ${ }^{3}$ Unidad de Investigación en Epidemiología Clínica, Unidad Médica de Alta Especialidad \\ Hospital de Pediatría, Centro Médico Nacional Siglo XXI, Instituto Mexicano del Seguro Social, Mexico City; ${ }^{4}$ Coordinación de Patología Bucal, \\ División de Estudios de Posgrado, Facultad de Odontología, Universidad Nacional Autónoma de México, Mexico City; ${ }^{5}$ Servicio de Estomatología, \\ Hospital Pediátrico de Sinaloa, Sinaloa; ${ }^{6}$ Servicio de Estomatología, Nuevo Hospital Civil de Guadalajara, Jalisco; ${ }^{7}$ Departamento de Oncología \\ Médica, Hospital Infantil de México Federico Gómez, Mexico City; ${ }^{8}$ Departamento de Oncología Médica, Instituto Nacional de Pediatría, Secretaría \\ de Salud, Mexico City. Mexico
}

\begin{abstract}
Background: Oropharyngeal mucositis (OM) is one of the primary complications arising during oncological treatment, which significantly reduces the patient's quality of life (QoL). The aim of this study was to translate, culturally adapt, and validate the use of a new Spanish version of the Oropharyngeal Mucositis-Specific Quality-of-Life instrument (OMQoL) for pediatric patients. Methods: A multicentric, cross-sectional validation study was conducted to translate and adapt OMQoL from English to Spanish for its use by children with OM aged 8-16 years. Reliability was measured using Cronbach's alpha; content and construct validity, in conjunction with exploratory factor analysis. The convergent validity, with the correlations of the scales for OM defined by the WHO, OMAS (Oropharingeal Mucositis Assessment Scale) and the PedsQL-3 cancer module in Spanish. Results: One hundred and ninety-three children with mean age of $10.91 \pm 2.38$ years participated in the study, out of which 101 (52.3\%) were females. In this sample, 80 children (41.5\%) suffered from acute lymphoblastic leukemia and $111(57.5 \%)$ had grade 2 and 3 OM. The factorial analysis resulted in four dimensions with loads $>0.40$. Among the 31 items of the OMQoL, six were eliminated. Cronbach alpha of OMQoL-Spanish was 0.954. Spearman's correlations $(r)$ with the OMS and OMAS scales were significant (with $r=-0.720$ and $r=-0.689 ; p<0.01$, respectively). Moderate correlation was observed with the PedsQL-3 cancer module $(r=0.426 ; p<0.01)$. Conclusions: OMQoL-Spanish demonstrated adequate psychometric properties, resulting in a reliable and valid instrument for measuring QoL in children with MO.
\end{abstract}

Key words: Mucositis. Quality of life. Validation. Instruments. Children.

Available online: $30-10-2019$ 


\section{Validación de un instrumento para medir la calidad de vida en niños con mucositis orofaríngea en tratamiento por cáncer}

\section{Resumen}

Introducción: La mucositis orofaríngea $(\mathrm{MO})$ es una de las principales complicaciones del tratamiento oncológico que reduce significativamente la calidad de vida (CV) del paciente. El objetivo fue traducir, adaptar de manera cultural y validar una nueva versión en español del instrumento Oropharyngeal Mucositis-Specific Quality-of-Life (OMQoL) en pacientes pediátricos. Métodos: Estudio transversal de validación, multicéntrico, realizado para la traducción y adaptación del OMQoL del inglés al español en pacientes de entre 8 y 16 años con MO. Se midió la confiabilidad mediante el Alfa de Cronbach; la validez del contenido y el constructo, con un análisis factorial exploratorio; y la validez convergente, con las correlaciones de las escalas para MO de la Organización Mundial de la Salud (OMS), la Oropharingeal Mucositis Assessment Scale (OMAS) y con el Pediatric Quality of Life-3 (PedsQL-3) módulo cáncer en español. Resultados: Participaron en el estudio 193 niños con una media de edad de $10.91 \pm 2.38$ años, de los cuales 101 (52.3\%) fueron de sexo femenino. En esta muestra, 80 niños (41.5\%) presentaron leucemia aguda linfoblástica y 111 (57.5\%) presentaron MO grado 2 y 3. El análisis factorial resultó con cuatro dimensiones con cargas > 0.40. De los 31 ítems del OMQoL, seis fueron eliminados. El Alfa de Cronbach del OMQoL español fue de 0.954. Las correlaciones de Spearman (r) con las escalas de la OMS y OMAS fueron significativas ( $r=-0.720$ y $r=-0.689 ; p<0.01$, respectivamente); con el PedsQL-3 módulo cáncer existió una moderada correlación ( $r=0.426 ; p<0.01)$. Conclusiones: La nueva versión del OMQoL en español demostró propiedades psicométricas adecuadas, y resulta un instrumento confiable y válido para medir la CV en niños con MO.

Palabras clave: Mucositis. Calidad de vida. Validación. Instrumentos. Niños.

\section{Introduction}

Patients under cancer treatment suffer from a series of cellular effects, mainly in cells with a high replication rate, such as those of the bone marrow, hair follicles, and oral cavity ${ }^{1}$. The direct damage of cytotoxic therapy to the oral tissues produces a frequent complication called oropharyngeal mucositis $(\mathrm{OM})^{2,3}$, a condition that is manifested as mucosal erythema and edema, leading to the formation of oral ulcers (Fig 1) $)^{4,5}$. OM generally occurs 3 to 5 days after starting chemotherapy and reaches its maximum intensity between days 7-10, close to the moment with the lowest neutrophil count. In the case of head and neck radiation, it occurs approximately at the end of the first week ${ }^{6-8}$. Patients with hematopoietic stem cell transplantation (HSCT) refer to $\mathrm{OM}$ as one of the most painful and debilitating complications $^{9}$. Morbidity in patients with severe $\mathrm{OM}$ is associated with pain, sometimes intractable and that requires narcotic analgesia. Also, it is associated with insufficient food and fluid intake that leads to malnutrition and dehydration with the subsequent requirement of parenteral nutrition, which results in psychological changes and difficulties in the cancer treatment, and significantly reduce the patient's quality of life $(\mathrm{Q} o \mathrm{~L})^{5,9,10}$. Not all patients undergoing chemotherapy develop OM, for which risk factors that increase its development have been described. These include age, due to the speed of epithelial mitosis 9,11 , the presence of more receptors for the epidermal growth factor in the epithelium $^{8,12}$, type of hematological neoplasia, oral situation before treatment, and degree of neutropenia and malnutrition. The frequency of oral complications occurs in up to $85 \%$ of patients with intense treatment with chemotherapy and radiotherapy ${ }^{13}$.

Health-related QoL is defined as a multidimensional construct that integrates the patient's perception about the impact of his disease and its treatment, as well as the patient's functioning in various aspects of life, including the physical, psychological, and social health areas ${ }^{14}$. The measurement of the QoL is based on subjective elements that require valid, reproducible and reliable instruments of evaluation ${ }^{15}$. When they are developed in other countries with the same or another language, they cannot be used in our population without first carrying out a process of translation, cultural adaptation and validation ${ }^{16}$.

There are instruments to assess the QoL of the patient with $\mathrm{OM}$ that evaluate the severity of symptoms, pain intensity, emotions, and physical limitations. Taken together, these variables interfere with daily life functions $^{17}$, thus the Oropharyngeal Mucositis-Specific Quality-of-Life (OMQoL) ${ }^{18}$ instrument evaluates the overall impact of OM on QoL from the patients' perspective. The purpose of this study was to translate, culturally adapt, and validate OMQoL in Mexican children undergoing cancer treatment. 


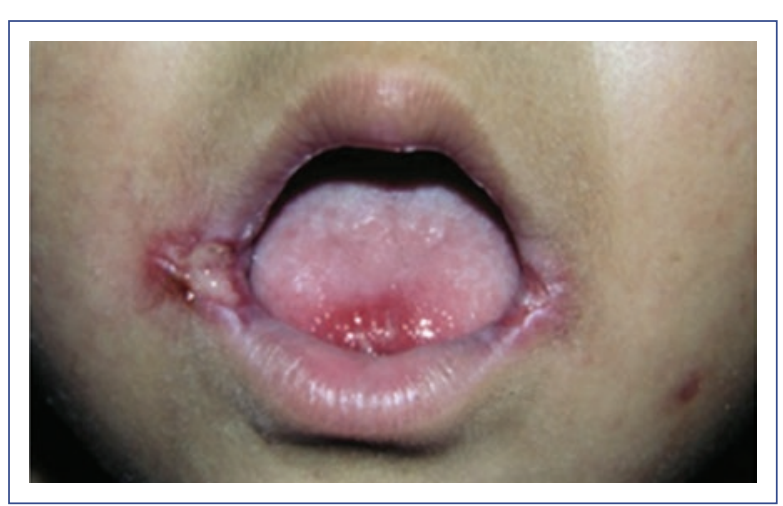

Figure 1. Patient with grade 2 oropharyngeal mucositis at the corners of the mouth, inner mucosa of the lips, and the tip of the tongue.

\section{Methods}

This multicenter cross-sectional validation study was conducted in four pediatric hospitals in Mexico between March 2015 and July 2016. The sample size was calculated according to the Cronbach's Coefficient Alpha (power: 0.80, $\alpha$ : 0.05, internal consistency: 0.70, K: 30) using the PASS Sample Size software 13. We included consecutive patients from 8 to 16 years of age, with a diagnosis of hematological neoplasm or solid tumor, treated with chemotherapy and radiotherapy or HSCT with varying degrees of $\mathrm{OM}$ who signed the informed consent and the informed assent. Those patients whose parents, guardians, or themselves could not read and answer the OMQoL autonomously were excluded. The study protocol was approved by the ethics and research committees of all the participating institutions.

The OMQoL was obtained directly from Dr. Karis Cheng, the original author. The instrument has 31 items that involve four dimensions (symptoms, diet, social function, and swallowing symptoms) to estimate QoL. Each item is scored from 1 to 4 , from "not at all" to "very much," concerning whether the respondent has had problems during the previous three days. All items are scored in reverse (for example, $1=4,2=3,3=2$ and $4=1$ ). Subscale scores are linearly transformed to a scale of 0 to 100 ([total of raw scores of each subscale item/maximum possible raw score of the total subscale items] x 100). High scores indicate a better QoL. The OMQoL in English presents an adequate reliability (Cronbach's alpha $>0.90$ ), convergent validity with the World Health Organization (WHO) scale for OM $(r=-0.724$ to $-0.971 ; p<0.01)$, and concurrent validity with the European Organization for Research and
Therapy of Cancer Quality of Life Questionnaire-30, Chinese version (EORTC QLQ-C30 [Ch]) $(r=0.450$ $0.724, p<0.01)^{18,19}$.

In this study, OM was evaluated with the WHO scale for $\mathrm{OM}^{2,20}$ and the Oral Mucositis Assessment Scale (OMAS), which measures erythema ( $0:$ none, 1 : mild/moderate and 2: severe) and ulceration or pseudo membrane (0: none, 1: $<1 \mathrm{~cm}^{2}, 2: 1-3 \mathrm{~cm}^{2}$ and $\left.3:>3 \mathrm{~cm}^{2}\right)$ in nine different sites of the oral cavity ${ }^{21}$. The oral assessments were carried out by three pediatric dentists with previous interobserver standardization (kappa $=0.72$ ). Subsequently, the participants completed the Pediatric Quality of Life-3 (PedsQL-3) cancer module (version for 8-12 and 13-18 years of age), adapted and validated in the Mexican population. This scale evaluates the QoL of children with cancer taking into account signs and symptoms such as pain, nausea, anxiety before procedures, anxiety before treatments, worries, cognitive problems, and physical appearance. Data were converted into the following: $0 \rightarrow 100,1 \rightarrow 75,2 \rightarrow 50,3$ $\rightarrow 25$ and $4 \rightarrow 0$. The final result is the average of the linear sum of the items; higher scores reflect adequate QoL ${ }^{22}$. Only instruments with $100 \%$ of items answered were included in the study.

For the statistical analysis, the SPSS software version 18 was utilized, and descriptive statistics were used to summarize the demographic and clinical characteristics. The content and construct validity were estimated with exploratory factor analysis. The Spearman correlation between the OMQOL and the WHO scale, OMAS, and the PedsQL-3 cancer module was determined to estimate the convergent validity. The internal consistency was estimated with the Cronbach's Alpha coefficient.

\section{Results}

The forward translation of OMQoL into Spanish was carried out by two independent translators. Subsequently, the two versions were unified, and the first version was integrated by a group of experts in measurement and QoL. Then, the back-translation of this version from Spanish into English was carried out by two different translators. The back-translated version was compared with the original, and the differences were resolved by expert consensus.

A pilot test was carried out in 25 patients with an average age of $10.6 \pm 1.5$ years, with different oncological diagnoses and $\mathrm{OM}$ degrees, to corroborate that the participants understood the new instrument. Before the scale application, a talk was given to show the parts of the oral cavity and explain key terms such as OM and 
ulcers. The new OMQoL in Spanish was given to the participants to read it, and they were asked to make suggestions and comments regarding the instrument. The approximate application time of the test was 15 minutes. The participants suggested changing specific terms that were not clear to them. The words and phrases "swelling", "distresses me", "redness", "burning sensation", "I have difficulty", "nutritious", "lower voice and it is not clear", "to sip", "solid" and "swallow" were changed to "swollen", "worries me", "red", "burns", "I have a hard time", "healthy", "I speak softly, and people do not understand me", "I drink", "hard" and "to swallow the food or saliva".

Moreover, the statement "I have my expression (including smiling to others) and communication affected" was changed to "My face, my smile, and my communication with others are not the same as before." Due to the suggestions and modifications, a second pilot test was carried out in 18 patients with similar characteristics, where most of the statements were well understood. The new version in Spanish of the OMQoL adapted for Mexican children was conformed. In the pilot tests, it was observed that most of the children had intravenous lines in veins of one or both hands, so in these cases, the children indicated the answer, and the researcher or the parents circulated it.

Afterward, 193 consecutive participants were included, with a median age of 11 years (mean $10.91 \pm 2.381$, range 8-16); $52.3 \%$ (101) were female, 63 (32.6\%) had OM grade 2 and 48 (24.9\%), grade 3 (Fig 1). The clinical characteristics are described in Table 1. In order to obtain the psychometric characteristics of the OMQoL in Spanish, the descriptive statistics for the 31 items were calculated (Table 2). Subsequently, the discriminative power of the items was tested, that is, their ability to detect differences in the quantities of the measured attribute, which according to Magnusson ${ }^{23}$, can be done by proving that there is a systematic relationship between the item scores and the total test score. For this, a comparison was made between extreme groups and the total test score (scores lower than the first quartile and higher than the third quartile) with the Mann Whitney $\mathrm{U}$ test, which was selected because of the non-parametric distribution of the items. All the items were conserved because they discriminated significantly.

With this data, an internal consistency analysis was performed, and a Cronbach's alpha of 0.963 was obtained. A correlation analysis between the items and the total of the sum of them was also performed to identify the type of factor extraction method and the rotation method necessary for the data obtained. With
Table 1. Clinical characteristics of the participants of the $\mathrm{OMOoL}$ in Spanish adapted for children validation study

\begin{tabular}{|c|c|}
\hline Characteristics & $\begin{array}{c}\text { Frequency (\%) } \\
\qquad \begin{array}{c}\mathrm{N}=193\end{array}\end{array}$ \\
\hline $\begin{array}{l}\text { Diagnosis } \\
\text { Pre-B ALL } \\
\text { AML } \\
\text { Osteosarcoma } \\
\text { Non-Hodgkin's lymphoma } \\
\text { Alveolar rhabdomyosarcoma } \\
\text { Ewing sarcoma } \\
\text { Embryonal rhabdomyosarcoma } \\
\text { T-cell lymphoblastic lymphoma } \\
\text { Pre-T ALL } \\
\text { Hodgkin's lymphoma } \\
\text { Malignant schwannoma } \\
\text { Others }\end{array}$ & $\begin{array}{c}80(41.5) \\
26(13.5) \\
18(9.3) \\
9(4.7) \\
9(4.7) \\
8(4.1) \\
4(2.1) \\
4(2.1) \\
4(2.1) \\
3(1.6) \\
2(1.0) \\
26(13.4)\end{array}$ \\
\hline $\begin{array}{l}\text { Cancer treatment } \\
\text { Chemotherapy } \\
\text { Chemotherapy/Radiotherapy } \\
\text { HSCT } \\
\text { Radiotherapy }\end{array}$ & $\begin{array}{c}176(91.2) \\
12(6.2) \\
3(1.6) \\
2(1.0)\end{array}$ \\
\hline $\begin{array}{l}\text { Phase of treatment } \\
\text { Induction } \\
\text { Consolidation } \\
\text { Maintenance } \\
\text { First cycle } \\
\text { Second cycle } \\
\text { Third cycle } \\
\text { Fourth cycle } \\
\text { Reinduction }\end{array}$ & $\begin{array}{c}50(25.9) \\
35(18.2) \\
25(13) \\
17(8.8) \\
8(4.1) \\
7(3.8) \\
11(5.7) \\
10(5.2)\end{array}$ \\
\hline $\begin{array}{l}\text { Chemotherapy } \\
\text { MTX } \\
\text { MTX-6MP } \\
\text { VCR-DOX-CTX } \\
\text { MTX-L-aspar-Dexamethasone } \\
\text { MTX-VP16-AraC } \\
\text { L-aspar } \\
\text { VCT-L-aspar-Dauno } \\
\text { IFO-DOX } \\
\text { Cisplatin-DOX } \\
\text { MTX-VCR } \\
\text { VCR } \\
\text { MTX-VP16-CFM } \\
\text { VP16-CFM } \\
\text { VCR- L-aspar } \\
\text { Others }\end{array}$ & $\begin{array}{c}19(9.8) \\
13(6.7) \\
12(6.2) \\
11(5.7) \\
9(4.7) \\
8(4.1) \\
7(3.6) \\
6(3.1) \\
5(2.6) \\
5(2.6) \\
5(2.6) \\
4(2.1) \\
4(2.1) \\
4(2.1) \\
112(41.9)\end{array}$ \\
\hline $\begin{array}{l}\text { OM grade (WHO) } \\
\text { Grade } 0 \\
\text { Grade } 1 \\
\text { Grade } 2 \\
\text { Grade } 3 \\
\text { Grade } 4\end{array}$ & $\begin{array}{c}20(10.4) \\
44(22.8) \\
63(32.6) \\
48(24.9) \\
18(9.3)\end{array}$ \\
\hline OMA value & $\begin{array}{c}\text { Median } \\
0.60(0-2.5)\end{array}$ \\
\hline $\begin{array}{l}\text { Type of nutrition } \\
\text { Tolerates the oral route } \\
\text { Tolerates only liquids } \\
\text { Parenteral } \\
\text { Enteral }\end{array}$ & $\begin{array}{c}127(65.8) \\
48(24.9) \\
13(6.7) \\
5(2.6)\end{array}$ \\
\hline
\end{tabular}


Table 1. Clinical characteristics of the participants of the $\mathrm{OMO} \mathrm{L}$ in Spanish adapted for children validation study (Continuation)

\begin{tabular}{|l|c|}
\hline Characteristics & $\begin{array}{c}\text { Frequency (\%) } \\
\text { N }=193\end{array}$ \\
\hline Type of analgesic & \\
Without analgesic & $59(30.5)$ \\
Non-opioid analgesic & $109(56.5)$ \\
Opioid analgesic & $25(13)$ \\
\hline
\end{tabular}

*Data are presented as a number, percentage, standard deviation $( \pm)$, and range. $A L L$, acute lymphoblastic leukemia; AML, acute myeloblastic leukemia; Ara-C, cytarabine; CTX, cyclophosphamide; Dauno, daunorubicin; DOX, doxorubicin; HSCT, hematopoietic stem cell transplantation; IFO, ifosfamide; L-aspar, L-asparaginase; MTX, methotrexate; OM, oropharyngeal mucositis; OMAS, Oropharyngeal Mucositis Assessment Scale; VCR, vincristine; VP16, etoposide; WHO, World Health Organization; 6-MP, 6-mercaptopurine.

this test, it was observed that the data presented medium to high correlations ( $\geq 0.60$ ), so the Principal Axis Method of Factor Extraction and the Promax oblique rotation method were chosen ${ }^{24}$.

The results showed a Kaiser Meyer Olkin measure of sampling adequacy of 0.952 and Bartlett's test of sphericity ( $p \leq 0.001)$, which indicates a high degree of joint relationship of the variables, thus making this appropriate to perform a factor analysis (Table 3). Two items (18 and 21 with factor loadings of 1.003 and 1.000 , respectively) were eliminated because they were Heywood cases (given that the solution is not interpretable because it has commonalities $\geq 1$ and due to the impossibility of having more than $100 \%$ of variance $)^{24}$. Similarly, items $10,12,15$, and 19 of the diet dimension were eliminated because they presented factor loadings $<0.40$ in the four factors ${ }^{25}$.

The exploratory factor analysis indicated that the scale consists of four factors that explain $56.672 \%$ of the variance with 25 items (construct validity). Again, the reliability of the new version of the OMQoL in Spanish was calculated, and a Cronbach's alpha of 0.954 (95\% Cl: 0.941-0.972) was obtained. The correlation between the OMQoL in Spanish and the WHO scale for OM was significant $(r=-0.720, p<0.01)$, as with the OMAS scale $(r=-0.689, p<0.01)$. The correlation with the PedsQL-3 cancer module for children was moderate but significant $(r=0.426 ; p<0.01)$, and resulted in an adequate convergent validity (Table 4).

\section{Discussion}

The focus in the relationship between the QoL and $\mathrm{OM}$ is continuously growing as an area of integral evaluation of oncological therapy. However, the information in children is limited because there are no specific instruments for this age group. For this reason, sometimes generic instruments that are used and designed for adults are also used to estimate it in children. Examples of these instruments are the Oral Health Impact Profile-14, which omits signs and symptoms, such as bleeding, burning mouth, salivary perception, phonation, swallowing, dysgeusia and throat discomfort, which are frequently reported by patients with $\mathrm{OM} ; 26,27$ the Functional Assessment of Cancer Therapy-Head and Neck; ${ }^{28}$ and the European Organization for Research and Therapy of Cancer-Quality of Life Questionnaire-3029. All of them have limited utility for the vast symptomatology that the OM present. Others, such as the Patient-Reported Oral Mucositis Symptoms ${ }^{30}$ and the Oral Mucositis Weekly Questionnaire-Head and Neck Cancer ${ }^{31}$, measure the symptoms of OM -excluding a whole spectrum of characteristics that surround it- and do not include elements to evaluate QoL.

In the present study, 80 patients $(41.5 \%)$ had acute lymphoblastic leukemia, the malignancy that affects about $50 \%$ of children with cancer, followed by myeloid leukemia and lymphoma. Patients with solid tumors mainly presented osteosarcoma since it is the type of tumor that most affects adolescents. These diseases are treated with intense treatment protocols that produce myelosuppression and damage to the mucous membranes, which influence the proportion of the different degrees of OM: the group with grade 4 was the one with the lowest percentage (9.3\%). The psychometric evaluation of the new version of the OMQoL in Spanish revealed that the items were representative of the QoL and OM as they presented an adequate convergent validity, despite having adaptations for its translation to Spanish and the adaptation for children. The factor analysis showed a new order in the dimensions: the subscale of social function was placed as the first dimension (nine items), followed by symptoms (seven items), swallowing (six items), and diet (three items). With this, it was possible to explain why in our culture, expression and communication are highly important, followed by the evident malaise that OM produces. Despite the elimination of five items on the subscale of diet ("I am unable to enjoy food", "My saliva becomes thick or sticky, and I need to spit frequently", "It takes me more time to eat or drink", "I worry about my inadequate nutritional intake and not being healthy", "I eat less soft and solid foods" and "I have difficulty in speaking"), and one of social function ("I have difficulty in speaking"), the instrument kept an adequate reliability (Cronbach's Alpha $=0.954$ ). 
Table 2. Results of the analysis of the statements of the OMQoL-Spanish adapted for children

Statement

1. My mouth is swollen

2. I have ulcers in my mouth

3. The pain in my mouth worries me

4. I have pus or blood on my lips or inside my mouth

5. I feel discomfort while brushing my teeth or rinsing my mouth

6. Mouth pain makes me have sleep troubles

7. I have mouth pain

8. I have red or burning sensation inside my mouth

9. I have a hard time opening my mouth

10. I am unable to enjoy food

11. I do not like eating out of my house because of the discomfort in my mouth

12. My saliva becomes thick or sticky, and I need to spit frequently

13. I have taste changes

14. Eating difficulty makes me distressed

15. It takes me more time to eat or drink

16. I have lost weight

17. I modified my diet

18. I eat less soft and solid foods

19. I worry about my inadequate nutritional intake and not being healthy

20. I speak softly, and people do not understand me

21. I have difficulty in speaking

22. I need to use other means (for example, paper and pen or signs) to communicate with others

23. I feel embarrassed when eating with my family and friends

24. Speaking difficulty worries me

25. I do not want to talk to other people (including on the phone) due to mouth discomfort

26. My face, my smile and my communication with others are not the same as before

27. I have throat discomfort

28. I drink a few liquids (for example, water, juice or soup)

29. It is hard for me swallowing soft and solid food

30. I feel easily choked while swallowing liquids, food, and saliva

31. It is hard for me swallowing saliva

OMQoL, Oropharyngeal Mucositis-Specific Quality-of-Life \begin{tabular}{|l|l|l} 
Mean & Standard deviation & Bias
\end{tabular}

\begin{tabular}{|l|l|l|}
\hline 2.98 & 1.005 & -0.69 \\
\hline
\end{tabular}

\begin{tabular}{|l|l|l|}
\hline 2.91 & 0.936 & -0.616 \\
\hline
\end{tabular}

2.99

3.46

1.005

$-0.727$

1.550

$-0.942$

1.231

$-1.235$

$-1.030$

$-0.829$

$-1.195$

$-1.390$

$-1.270$

$-0.674$

$-0.992$

$-1.284$

$-0.994$

$-1.290$

$-1.268$

$-1.126$

$-0.827$

$-0.799$

1.586

0.884

1.720

$-0.209$

$-0.600$

$-1.045$

$-0.856$

$-0.226$

$-1.028$

1.383

$-0.656$
When an instrument is culturally adapted to a country with a different language from the original and, as in this case, for a different age, it is likely that some items will not be well understood or will be irrelevant, which is reflected in low factor loadings, and the consequent need to eliminate items since keeping them could lead 
Table 3. Factor loadings of the rotated component matrix of the OMOoL-Spanish adapted for children

\begin{tabular}{|c|c|c|c|c|}
\hline \multirow[t]{3}{*}{ Items } & \multicolumn{4}{|c|}{ Factor loadings } \\
\hline & \multicolumn{4}{|c|}{ Factor } \\
\hline & 1. Social function & 2. Symptoms & 3. Swallowing & 4. Diet \\
\hline $\begin{array}{l}\text { 25. I do not want to talk to other people (including on the } \\
\text { phone) due to mouth discomfort }\end{array}$ & 0.947 & -0.042 & -0.044 & 0.083 \\
\hline 24. Speaking difficulty worries me & 0.898 & -0.005 & 0.008 & -0.023 \\
\hline 20. I speak softly, and people do not understand me & 0.847 & -0.164 & 0.076 & 0.108 \\
\hline $\begin{array}{l}\text { 22. I need to use other means (for example, paper and pen or } \\
\text { signs) to communicate with others }\end{array}$ & 0.844 & -0.073 & 0.017 & 0.033 \\
\hline 23. I feel embarrassed when eating with my family and friends & 0.694 & 0.068 & 0.094 & -0.300 \\
\hline 9. I have a hard time opening my mouth & 0.473 & 0.378 & -0.166 & 0.157 \\
\hline 14. Eating difficulty makes me distressed & 0.470 & 0.370 & -0.060 & 0.132 \\
\hline $\begin{array}{l}\text { 11. I do not like eating out of my house because of the } \\
\text { discomfort in my mouth }\end{array}$ & 0.427 & 0.226 & 0.077 & 0.020 \\
\hline $\begin{array}{l}\text { 26. My face, my smile and my communication with others are } \\
\text { not the same as before }\end{array}$ & 0.423 & 0.1940 & 0.065 & 0.207 \\
\hline 5. I feel discomfort while brushing my teeth or rinsing my mouth & -0.187 & 0.848 & -0.053 & 0.046 \\
\hline 2. I have ulcers in my mouth & 0.148 & 0.695 & -0.104 & 0.099 \\
\hline 3. The pain in my mouth worries me & -0.009 & 0.672 & 0.100 & -0.009 \\
\hline 1. My mouth is swollen & 0.040 & 0.566 & 0.162 & -0.012 \\
\hline 8. I have red or burning sensation inside my mouth & 0.035 & 0.499 & 0.078 & 0.199 \\
\hline 4. I have pus or blood on my lips or inside my mouth & 0.188 & 0.447 & 0.144 & -0.292 \\
\hline 6. Mouth pain makes me have trouble sleep & 0.087 & 0.422 & 0.275 & -0.110 \\
\hline 27. I have throat discomfort & -0.037 & 0.008 & 0.788 & 0.067 \\
\hline 31. It is hard for me swallowing saliva & 0.011 & 0.003 & 0.786 & 0.118 \\
\hline $\begin{array}{l}\text { 30. I feel easily choked while swallowing liquids, food, and } \\
\text { saliva }\end{array}$ & 0.068 & 0.159 & 0.703 & -0.079 \\
\hline 28. I drink a few liquids (for example, water, juice or soup) & 0.168 & 0.014 & 0.509 & -0.004 \\
\hline 13. I have taste changes & -0.124 & -0.134 & 0.453 & 0.371 \\
\hline 29. It is hard for me swallowing food (soft and solid) & 0.228 & 0.131 & 0.451 & 0.086 \\
\hline 7. I have mouth pain & -0.132 & 0.140 & -0.020 & 0.615 \\
\hline 16. I have lost weight & 0.130 & -0.220 & 0.155 & 0.545 \\
\hline $\begin{array}{l}\text { 17. I modified my diet (for example, the type of food, shape, and } \\
\text { size) }\end{array}$ & 0.011 & 0.252 & 0.077 & 0.543 \\
\hline
\end{tabular}

OMQoL, Oropharyngeal Mucositis-Specific Quality-of-Life.

to an information and interpretation bias on the part of the participants ${ }^{16}$.

The correlations of the OMQoL with the OM scales (WHO and OMAS) showed an adequate convergent validity, while the correlation with the PedsQL-3 was moderate. Possibly, this is because the PedsQL-3 evaluates more areas of life, which, although they could be related to $\mathrm{OM}$, do not focus on the same evaluation criteria, but rather involve a series of variables to which oncological patients are exposed. These variables include physical pain, fear of cannulation and bone marrow aspiration, nausea, fear of the medical staff or 
Table 4. Correlation between the OMOoL in Spanish with the PedsOL-3 cancer module, OM Scale (WHO) and OMAS Scale*

\begin{tabular}{|l|c|}
\hline $\begin{array}{l}\text { WHO scale for OM } \\
\text { (OM degree of severity) } \\
\text { for children, } \boldsymbol{p} \text {-value }\end{array}$ \\
\hline OMAS Scale & $-0.735^{* *}$ \\
\hline $\begin{array}{l}\text { PedsQL-3 cancer module (8-12 } \\
\text { and } 13-18 \text { years of age) }\end{array}$ & $-0.690^{* *}$ \\
\hline
\end{tabular}

* Calculated by Spearman correlation.

** The correlation is significant, with a level of 0.01 (two tails)

$\mathrm{OM}$, oropharyngeal mucositis; OMQoL, Oropharyngeal Mucositis-Specific

Quality-of-Life; WHO, World Health Organization; OMAS, Oropharyngeal Mucositis Assessment Scale.

hospital, concern about the treatment's side effects, and impairment of physical appearance.

The evaluation of the QoL of patients with OM should be done with specific, reliable, and valid instruments for this association, since general instruments cannot capture the oropharyngeal signs and symptoms that can limit feeding, communication, and perceived physical appearance, among others. This occurs especially in children who, because of their young age, do not understand the prospect of their diagnosis and treatment, in addition to the pain in the mouth that they have -because of the ulcers-, the impression of oral bleeding and the inability to open the mouth or to communicate, which implies a great anguish and despair for them.

\section{Ethical disclosures}

Protection of human and animal subjects. The authors declare that no experiments were performed on humans or animals for this study.

Confidentiality of data. The authors declare that they have followed the protocols of their work center on the publication of patient data.

Right to privacy and informed consent. The authors have obtained the written informed consent of the patients or subjects mentioned in the article. The corresponding author is in possession of this document.

\section{Conflicts of interest}

The authors declare that they have no conflicts of interest.

\section{Funding}

None.

\section{Acknowledgments}

We acknowledge all the children with cancer and their parents who agreed to participate in this research.

\section{References}

1. Caribé-Gomes F, Chimenos-Küstner E, López-López J, Finestres-Zubeldia F, Guix-Melcior B. Manejo odontológico de las complicaciones de la radioterapia y quimioterapia en el cáncer oral. Med Oral. 2003;8:178-87.

2. Peterson DE, Bensadoun RJ, Roila F. Management of oral and gastrointestinal mucositis: ESMO Clinical Practice Guidelines. Ann Oncol. 2011;22:vi78-vi84.

3. Sonis ST, Elting LS, Keefe D, Peterson DE, Schubert M, Hauer-Jensen M, et al. Perspectives on cancer therapy-induced mucosal injury. Cancer. 2004;100:1995-2025.

4. Ruiz-Esquide G, Nervi B, Vargas A, Maíz A. Tratamiento y prevención de la mucositis oral asociada al tratamiento del cáncer. Rev Med Chile. 2011;139:373-81.

5. Otmani N, Alami R, Hessissen L, Mokhtari A, Soulaymani A, Khattab M. Determinants of severe oral mucositis in paediatric cancer patients: a prospective study. Int J Paediatr Dent. 2011;21:210-6.

6. Cheng KK. Oral mucositis and quality of life of Hong Kong Chinese patients with cancer therapy. Eur J Oncol Nurs. 2007;11:36-42.

7. Soares AF, Aquino AR, Carvalho CH, Nonaka CF, Almeida D, Pinto LP. Frequency of oral mucositis and microbiological analysis in children with acute lymphoblastic leukemia treated with $0.12 \%$ chlorhexidine gluconate. Braz Dent J. 2011;22:312-6.

8. Hernández FA, Oñate SRE, Cabrerizo MMC, De- Arriba-de-la-Fuente F, Heras FI, García VV. Influence of oral health on mucositis in patients undergoing hematopoietic progenitor cell transplantation (HPCT). Med Oral Patol Oral Cir Bucal. 2012;17:e94-101.

9. Raber-Durlacher JE, Barasch A, Peterson DE, Lalla RV, Schubert MM, Fibbe WE. Oral complications and management considerations in patients treated with high-dose chemotherapy. Support Cancer Ther. 2004:1:219-29.

10. Sonis ST, Oster G, Fuchs H, Bellm L, Bradford WZ, Edelsberg J, et al. Oral mucositis and the clinical and economic outcomes of hematopoietic stem-cell transplantation. J Clin Oncol. 2001;19:2201-5.

11. Cheng KK, Goggins WB, Lee VW, Thompson DR. Risk factors for oral mucositis in children undergoing chemotherapy: a matched case-control study. Oral Oncol. 2008;44:1019-25.

12. Joshi VK. Dental treatment planning and management for the mouth cancer patient. Oral Oncol. 2010;46:475-9.

13. Cheng KKF, Lee V, Li CH, Goggins W, Thompson D, Yuen HL, et al. Incidence and risk factors of oral mucositis in paediatric and adolescent patients undergoing chemotherapy. Oral Oncol. 2011;47:153-62.

14. Sitaresmi MN, Mostert S, Gundy CM, Sutaryo, Veerman AJ. Health-related quality of life assessment in Indonesian childhood acute lymphoblastic leukemia. Health Qual Life Outcomes. 2008;6:96-102.

15. Velarde-Jurado E, Avila-Figueroa C. Consideraciones metodológicas para evaluar la calidad de vida. Salud Publica Mex. 2002;44:448-63.

16. Ramada-Rodilla JM, Serra-Pujadas C, Delclós-Clanchet GL. Adaptación cultural y validación de cuestionarios de salud: revisión y recomendaciones metodológicas. Salud Publica Mex. 2013;55:57-66.

17. Rosenthal DI, Mendoza TR, Chambers MS, Burkett VS, Garden AS, Hessell AC, et al. The M. D. Anderson symptom inventory-head and neck module, a patient-reported outcome instrument, accurately predicts the severity of radiation-induced mucositis. Int J Radiation Oncology Biol Phys. 2008;72:1355-61.

18. Cheng KKF, Leung SF, Thompson DR, Tai JW, Liang RH, Kan AS, et al. New measure of health-related quality of life for patients with oropharyngeal mucositis development and preliminary psychometric evaluation. Cancer. 2007;109:2590-9.

19. Cheng KKF, Leung SF, Liang RH, Tai JW, Yeung RM, Thompson DR. A patient-reported outcome instrument to assess the impact of oropharyngeal mucositis on health-related quality of life: a longitudinal psychometric evaluation. Support Care Cancer. 2009;17:389-98.

20. Lopez CF, Oñate SR, Rodal C, Cabrerizo M. Measurement of secondary mucositis to oncohematologic treatment by means of different scale. Review. Med Oral Patol Oral Cir Bucal. 2005;10:412-21.

21. Sung L, Tomlinson GA, Greenberg ML, Koren G, Judd P, Ota S, et al. Validation of the oral mucositis assessment scale in pediatric cancer. Pediatr Blood Cancer. 2007;49:149-53.

22. Varni JW, Burwinkle TM, Katz ER, Meeske K, Dickinson P. The PedsQL in pediatric cancer, reliability and validity of the Pediatric Quality of Life Inventory Generic Core Scales, Multidimensional Fatigue Scale, and Cancer Module. Cancer. 2002;94:2090-106.

23. Magnusson D. Teoría de los tests. Mexico: Trillas;1998. 
24. Fabrigar LR, Duane WT, MacCallum RC, Strahan EJ. Evaluating the use of exploratory factor analysis in psychological research. Psychol Methods. 1999;4:271-99.

25. Nunnally JC. Teoría psicométrica. Mexico: Trillas;1995.

26. Bardellini E, Amadori F, Majorana A. Oral hygiene grade and quality of life in children with chemotherapy-related oral mucositis: a randomized study on the impact of a fluoride toothpaste with salivary enzymes, essential oils, proteins and colostrum extract versus a fluoride toothpaste without menthol. Int J Dent Hyg. 2016;14:314-9.

27. Bezinelli LM, Eduardo FP, Neves VD, Correa L, Lopes RM, Michel-Crosato $E$, et al. Quality of life related to oral mucositis of patients undergoing haematopoietic stem cell transplantation and receiving specialised ora care with low-level laser therapy: a prospective observational study. Eur J Cancer Care (Engl). 2016;25:668-74.
28. Gautam PA, Fernandes DJ, Vidyasagar MS, Maiya AG, Nigudgi S. Effect of low-level laser therapy on patient reported measures of oral mucositis and quality of life in head and neck cancer patients receiving chemoradiotherapy - a randomized controlled trial. Support Care Cancer. 2013:21:1421-8.

29. Lima AG, Antequera R, Peres MP, Snitcosky IM, Federico MH, Villar RC. Efficacy of low-level laser therapy and aluminum hydroxide in patients with chemotherapy and radiotherapy-induced oral mucositis. Braz Dent J. 2010;21:186-92.

30. Kushner JA, Lawrenc HP, Shoval I, Kiss TL, Devins GM, Lee L, et al. Development and Validation of a Patient-Reported Oral Mucositis Symptom (PROMS) Scale. J Can Dent Assoc. 2008;74:59.

31. Epstein JB, Robertson M, Emerton S, Phillips N, Stevenson-Moore P. Quality of life and oral function in patients treated with radiation therapy for head and neck cancer. Head Neck. 2001;23:389-98. 